DOI: $10.21625 /$ archive.v2i2.245

\title{
The Iconographic Method Applied in the Design of Products with Cultural Demostration in the Creation of the Tourist Destination
}

\author{
Daniel Marcelo Acurio M. ${ }^{1}$, Santiago Alejandro Acurio M. ${ }^{1}$, Cristina Páez Quinde ${ }^{2}$, \\ Daniel Sánchez Guerrero ${ }^{3}$, Ruth Infante Paredes ${ }^{2}$, Marcelo Núñez Espinoza ${ }^{2}$ \\ ${ }^{1}$ Pontificia Universidad Católica del Ecuador Sede Ambato.
}

${ }^{2}$ Facultad de Ciencias Humanas y de la Educación, Universidad Técnica de Ambato. Email (mc.paez, ruthinfantep, marcelownuneze)

${ }^{3}$ Universidad Estatal Amazónica - Puyo.

\section{Keywords}

Iconography; culture; popular festivities, Corpus Christi, touristic destination;

\begin{abstract}
The popular festivity known as Corpus Cristi is a clear manifestation of culture in Ecuador. It is considered a crosscultural expression of the cosmovision and iconographic symbolism of religious fusion making an evident imaginary connotation of the population. Where evident, catholics are of a vernacular world and end up being a praise in honor of the favors received from the Body of Christ and the indigenous roots of spirituality. It represents gratitude for the successful harvests obtained in the year by the Pachamama and Taita Inti. The present study aims to provide furnishings with designs of this festival, the park 13 de abril in Pujilí, which is also commonly known by locals as the Danzante Park. The methodology used was an analysis of the artistic projects developed by Panofsky where the work is reinterpreted from a designer perspective. This method is used to propose a method of extracting the iconographic and iconological elements of cultural demonstrations resulting in the innovation of the canton. Taking advantage of the values and cultural heritage of the nation and showcasing its aesthetics, a greater flow of visitors to the area is ensured as well as the dynamics of the local economy.
\end{abstract}

\section{Introduction}

Iconography has been considered, both, from a scientific point of view (Porebski, 1969) and an artistic one (Panofsky E. , 1987) as a technique of description and classification of images understood as a visual representation. For Panofsky, there is a connection between an iconic work of art and a morphological and semantic component. In Mieczyslaw Porqbski’s study of Polish art, images contain informative elements that bring meaning. The Panofsky method, although widely applied, runs the risk of finding un-coded content or unintended meanings within the images (Bialostocki, 1973). An icon is commonly defined as a sign that maintains a relation of resemblance to the represented DRAE (Mitchell, 2015). However, and although this definition intrinsically includes the semiotic sing significance as an element that brings meaning to the represented form (Zhang \& Sheng, 2017), it still gives greater prominence to its form in the relational sense with the represented object. In other words, meaning of the represented object is the only given thing. Thus, to represent a real object, such as a cup, an icon must resemble the shape of that cup. That, nonetheless, excludes meanings associated with the icon of that cup that could mean the proximity of a coffee place; a geographical area traditionally associated with its production or a place of recreation in which you can chat and enjoy a relaxed atmosphere even though coffee or another beverage that is served in a cup is not consumed. The cognitive processes studied by Olson \& Bialystok (2014) show that a new observed image is contrasted with a set of previously acquired concepts that activate mental processes of assimilation and interpretation that associates concepts acquired with the image. 
For this reason, and for the purposes of the present work, the broad definition of icon is adopted as a "discursive unit, spatially delimited (by a real or virtual framework) within the appearance of the signals, which may indicate one or several referents (Colle, 1999). Understood as a discursive unit, the icon gives rise to a form of "codified" visual language with an ease of comprehension that allows the expression of a variety of emotions through the intentional inclusion of aesthetically pleasing "indicators".

Considering the level of meaning associated, levels of iconicity have been proposed. In addition to their own description, they are associated with their pragmatic functions (Villafañe, 1985). The eleven levels are shown in Table 1 as follows:

Table 1. Eleven levels of iconicity

\begin{tabular}{|c|c|c|c|}
\hline Degree & Level & Description & Function \\
\hline 11 & Natural image & $\begin{array}{l}\text { Restores all properties of the object. Is } \\
\text { perceived directly in the natural state }\end{array}$ & Recognition \\
\hline 10 & $\begin{array}{l}\text { Scale three dimensional } \\
\text { model }\end{array}$ & $\begin{array}{l}\text { Restores all properties of the object. Is } \\
\text { perceived directly but not in the } \\
\text { natural state }\end{array}$ & Description \\
\hline 9 & Stereoscopic record images & $\begin{array}{l}\text { Restores form, color and position of } \\
\text { the object. Is indirectly perceived } \\
\text { artificially }\end{array}$ & Description \\
\hline 8 & Color photography & $\begin{array}{l}\text { Highly restores the positional } \\
\text { relationship and color in a two } \\
\text { dimensional plane }\end{array}$ & Description / artistic \\
\hline 7 & $\begin{array}{l}\text { Black and White } \\
\text { photography }\end{array}$ & $\begin{array}{l}\text { Resets the relationships between form } \\
\text { and position in a two-dimensional } \\
\text { plane }\end{array}$ & Description / artistic \\
\hline 6 & Realistic painting & $\begin{array}{l}\text { Reasonably resets relationships } \\
\text { between form and position in a two- } \\
\text { dimensional plane }\end{array}$ & Artistic \\
\hline 5 & $\begin{array}{l}\text { Nonrealistic figurative } \\
\text { representation }\end{array}$ & $\begin{array}{l}\text { Does not reestablish relationships on a } \\
\text { two-dimensional plane but } \\
\text { identification still occurs }\end{array}$ & Artistic \\
\hline 4 & Pictograms & $\begin{array}{l}\text { Only the shape and not the other } \\
\text { relations or sensitive characteristics are } \\
\text { restored }\end{array}$ & Information \\
\hline 3 & Motivated schemes & $\begin{array}{l}\text { The sensitive features are removed and } \\
\text { only organic relationships are } \\
\text { represented }\end{array}$ & Information \\
\hline 2 & Arbitrary schemes & $\begin{array}{l}\text { There are no sensitive characteristics } \\
\text { or organic relationships generally } \\
\text { indicative }\end{array}$ & Information \\
\hline 1 & $\begin{array}{l}\text { Nonfigurative } \\
\text { representation }\end{array}$ & $\begin{array}{l}\text { Their sensitive properties and } \\
\text { relationships are abstracted, their } \\
\text { meaning is not evident }\end{array}$ & Artistic \\
\hline
\end{tabular}

Latin America and Ecuador have great cultural diversity (Kent, 2016). Since pre-Hispanic times, there has been an adaptation of elements of the people with whom they relate that required achieving a unique symbolic language in which great importance is given to the natural motifs from the vision of divinity and a symbiotic relationship. We find common motifs of birds, mountains, flowers, rivers, and more that adorn their clothing and personal objects (Leon, 2014). Over time, these elements and their "icons" have been losing their presence and meaning, becoming a commodity that often devalues cultural identity reuslting in a misconception of underdevelopment or social marginalization.

It is of social, touristic and economic interest to take advantage of these elements by giving them an air of modernity (Johnston, 2013). Assuming the permanent construction and reinterpretation of our cultural identity is not only understood as the reservation of ancestral elements representative of an indigenous nationality, but also as 
inputs for the construction of the future tradition (Larraín, 1994). At a graphic level in product design, in Latin America, (Restrepo, 2013 \& Newman, 2015) a road that has been transported in Ecuador, where industrial production prefers to leave aside cultural contribution, has been left at an artisan level. Since it does not have resources, little chances of innovation are left in the creation of products and relating them to cultural aspects, with an exception to the field of costume design.

From this perspective, incorporating a broad theoretical reference of iconographic studies developed in the field of plastic arts will allow a methodological reference that will help professionals in determining aesthetic elements from this broad cultural background. It should also give them an opportunity to take advantage when it comes to the design of products that promote local development based on its own iconic elements, finally, strengthening the identity itself.

Although it is true that the study of artistic works has profound methodological proposals such as the case of Bilderatlas Mnemosyne raised for the iconological study by Abraham Moritz Warburg, better known by Aby Warburg, that considers a heuristic analysis of works of art and their relationship with religion, poetry, worship, and more. In his analysis, he investigates a variety of documents by constructing 82 panels which form part of his plan and provide a detailed meaning of the work in his own words: "der liebe Gott steckt im Detail" (Tartás \& Guridi, 2013). It is no less true that the method developed by his follower, Erwin Panofsky, provides more methodological rigor in a time that appropriately separates the scope of iconography as a study with a purely descriptive scope that regards iconology as an interpretative study. For this reason, it serves as a firm base that allows the development of a method that focuses on the design and constitutes innovation.

\section{Methods and Materials}

As per the previous discussion, it is imperative to feature the method proposed by Panofsky, which is summed up with a simple example that is mentioned such as a person greeting another by taking off his or her hat. In this simple action some levels, as follows, can be found:

- Primary or natural meaning in which only basic forms can be determined. In the example there are forms that shape the person greeting (factual significance) and their basic postural relationships that indicate their mood of greeting (expressive meaning).

- Secondary or conventional meaning: At this level, the conventional meaning that is socially accepted is at stake. Therefore, it is of unequivocal interpretation. In other words, the conscious recognition of taking off the hat implies a salutation. It is derived from the medieval custom of taking off the helmet in a sign of confidence, thus, it demonstrate the knight's peaceful intentions.

- Intrinsic meaning or content: While the previous levels are purely phenomenological, ie perceived by direct inspection. This level involves an inner knowledge, a description about the personality of the individual who greets as well as the underlying motivations and interests in the act of greeting. This would only be possible by investigating the individual from different points of view and in different environments. It becomes a synthesis of these individual attributes (Panofsky E. , 1987).

Thus, it clearly distinguishes levels of analysis:

- Pre-iconographic; Corresponding to primary meaning and it is based on practical experience, familiarity with objects and events. It can be corrected by a study of the way, in which in different historical conditions, objects were expressed by forms (style history).

- Iconographic; corresponding to the secondary meaning and which is based on a knowledge and familiarity with specific themes and concepts. It is corrected by a study on how, in different historical conditions, the themes and concepts were expressed through objects and events (history of types).

- Iconological; corresponding to intrinsic significance. It is based on familiarity with the essential tendencies of the human mind, which can be improved by a study of how, in different historical conditions, the essential tendencies of the mind were expressed through themes and concepts Specific (history of symbols). (Panofsky, Studies on iconology, 1998)

\section{Results and Discussion}

In recognizing the stages of this method, it is reasonable to see that, in of product design where the basic outlook is commercial in nature, the required level is the first because what is being conveyed to the consumer is an image of aesthetics that encloses a factual and expressive meaning of the product that generates familiarity and attractiveness. That also includes a social meaning according to the environment where the product is introduced (secondary meaning). However, its results, unlike arts, are difficult to apply and have little commercial value when trying to capture an inner, symbolic, non-factual image and translate it into an object of consumption. However, this is not impossible given that there are certainly a few consumer products that have marked not only identity and 
social acceptance, but have become cultural referents as well. For methodological purposes, it refers to the levels of sensitive perception.

In accordance with Panofsky's model, the levels of interpretation (Table 2) can be presetentative for elements of the cultural symbolic language, taking into consideration that this aesthetic interpretation aims at its application in a consumer product without being completely artistic or informative. According to the level of iconicity proposed by Villafañe, the product of the analysis must be located according to its complexity between a nonrealistic figurative representation and a pictogram. Thus, the levels are addressed as shown below:

Table 2. Levels of interpretation

\begin{tabular}{|c|c|c|c|}
\hline Level & Purpose & Technique & Correction method \\
\hline $\begin{array}{l}\text { Pre } \\
\text { iconographic }\end{array}$ & $\begin{array}{l}\text { - Recognize the basic sections that } \\
\text { make up the object of study and its } \\
\text { position (expressive meaning) } \\
\text { according to its visual weight. } \\
\text { - Simplify its basic forms. }\end{array}$ & $\begin{array}{ll}- & \text { Observation } \\
- & \text { Anecdotic } \\
& \text { register } \\
- & \text { Photographic } \\
& \text { collection }\end{array}$ & $\begin{array}{l}\text { Form simplification } \\
\text { (geometrization, } \\
\text { abstraction) }\end{array}$ \\
\hline Iconographic & 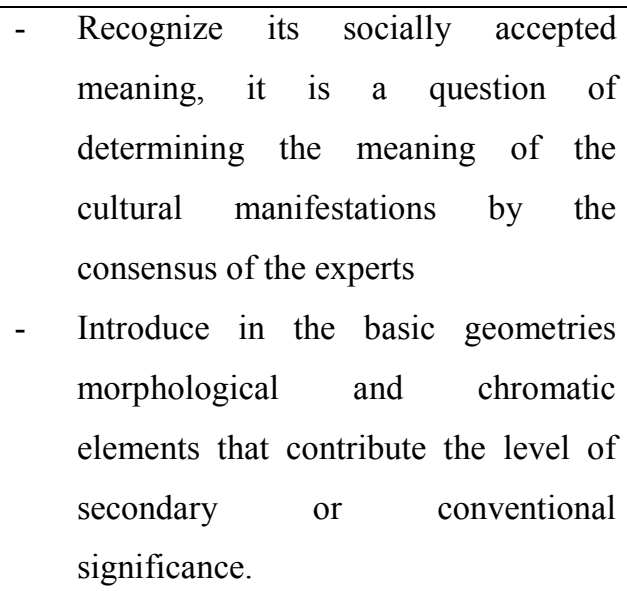 & $\begin{array}{ll}- & \text { Interview } \\
- & \text { Survey }\end{array}$ & $\begin{array}{l}\text { Principles of design } \\
\text { (repetition, radiation, } \\
\text { gradation, etc.) }\end{array}$ \\
\hline
\end{tabular}

As indicated, the aesthetic elements obtained must be of a basic level of complexity as to make their introduction into the product design feasible. It does not have to affect the functional performance and, at the same time, the cultural contribution has to be appreciated by its aesthetic component.

A first approximation was presented when the Park and garden were equiped for the re-evaluation of the iconic identity of Corpus Christi (Montenegro, 2014). The basic elements of the dancers of Corpus Christi, a festival of Pujilí in Cotopaxi by agreement No. 647 of the Ministry of Education, Culture, Sports and Recreation of Ecuador, were constituted as an intangible good belonging to the cultural heritage of the Nation.

In order to get a broader view of the origin and evolution of the feast of Corpus Christi, some authors with important information are quoted:

Corpus Christi comes from Latin "Corpus" which means "Body" and "Christi" which is translated as "of Christ". Therefore, "Corpus Christi" means "The Body of Christ".

This feast came from the end of the thirteenth century in Liege, Belgium. It was created by a Eucharistic movement whose center was the Abbey of Cornillon founded in 1124 by Bishop Albero de Liege. Among the various eucharistic customs that this movement began there are: the exposition and blessing of the Most Holy Sacrament, the use of the bells during the elevation at Mass and the feast of Corpus Christi (Herrera \& Monge, Corpus Christi, Intangible Heritage of Ecuador, 2012).

On the other hand, a series of events occurred and they contributed to the establishment of the feast of Corpus Christi. One of them was the Eucharistic revelations of St. Julian of Retine, prioress of a monastery near Liege. Another event was the miracle of the Bolsena Forms, as well as the miracle of the Corporal of Daroca (the hosts had become real flesh and could not be separated from the corporal or liturgical cloth that enveloped them due to the coagulated blood). The liturgical cloths were taken (to the pope) Urban IV, who stimulated by this and aware of 
the necessity to fight heresy of Berengario, established in 1264 the celebration of Corpus Christi in all the Church. (Pope) Clement V confirmed it in 1311 and since then it spread throughout the Catholic world (Valiente, 2011)

In the case of Ecuador, this celebration of religious and cultural origin came to our territory with the Spanish conquerors who checked that the indigenous peoples had several festivities. One of them was Inti Raymi that includes important characters like performers who dance in honor of the Sun in June (Figure 1). This month coincides with the religious celebration called Corpus Christi. This fact produced that the priests decided to incorporate the indigenous dancers in the catholic celebration.

In the colony, the indigenous feasts were gradually integrated into the Catholic holidays since, for the natives, it was not so easy to accept the imposition of the precepts of the Catholic Church.

According to Luis Moreno, the current popular feasts of Corpus Christi are survivors of the Inti Raymi, heliolatric ceremony of the ancient Kingdom of Quito.

Corpus Christi is a festival of important national significance that originally was a purely indigenous celebration. Over time, it was combined with the Catholic religious festival integrating elements and characteristics that were highlighting the popular manifestations of Ecuador that remain alive in the country (Herrera, Corpus Christi, Intangible Heritage of Ecuador, 2011)

With the above, the knowledge of the feast of Corpus Christi is amplified and the proposed method is applied.

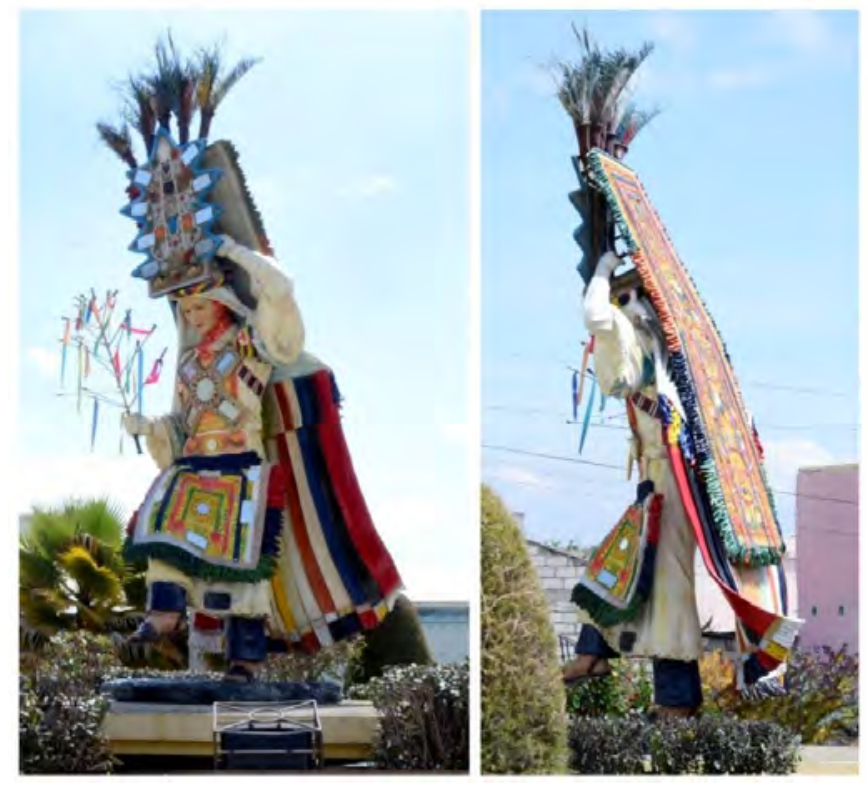

Figure 1. Corpus Christi Dancer

From which the proposed method is applied as follows (tables 3-4):

Table 3. Pre iconographic level

\begin{tabular}{|c|c|c|}
\hline BASIC & REGISTER & SIMPLIFICATION \\
SECTIONS & & \\
\hline & &
\end{tabular}




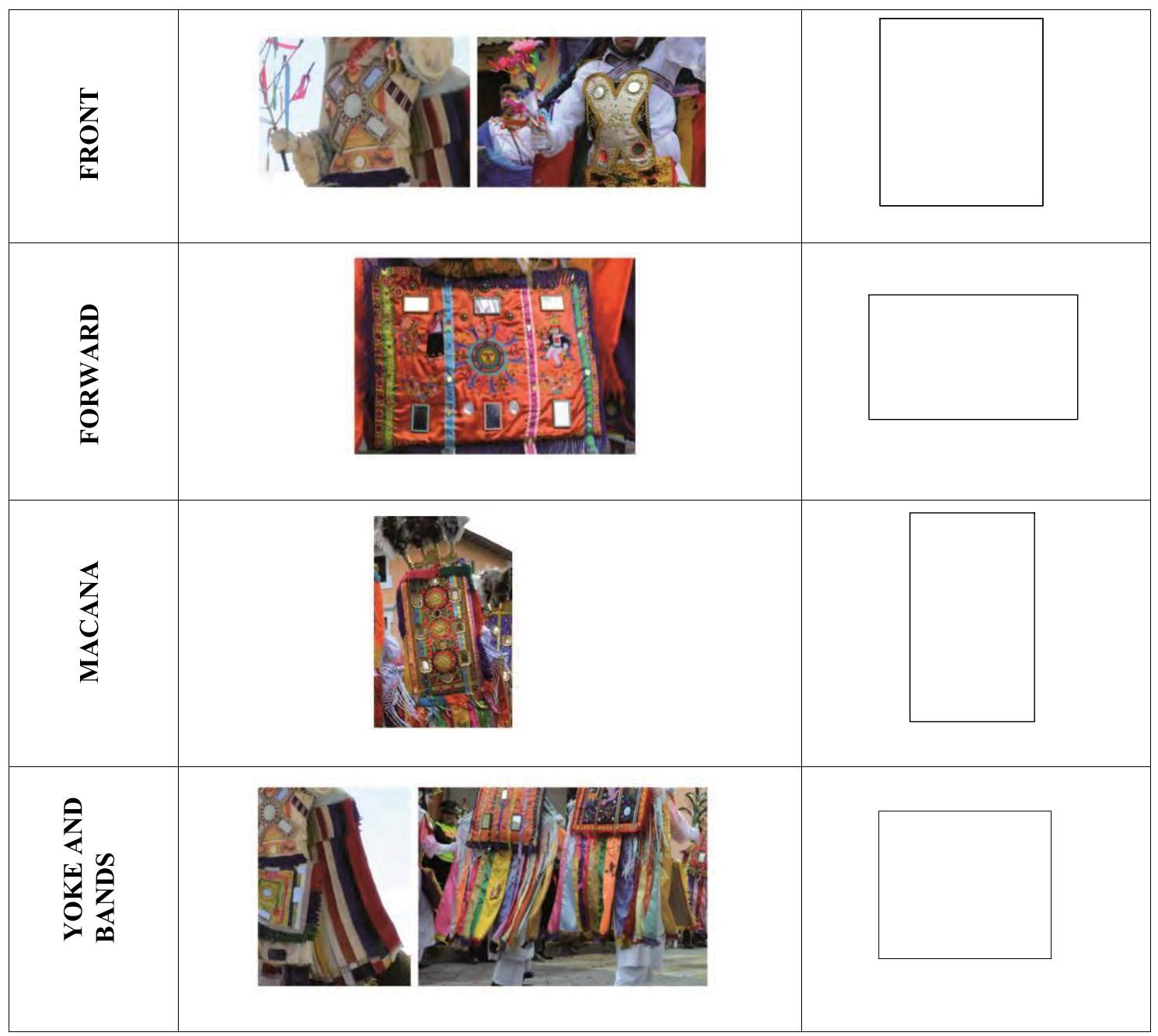

Table 4. Iconographic level

\begin{tabular}{|c|c|c|c|}
\hline $\begin{array}{c}\text { BASIC } \\
\text { SECTIONS }\end{array}$ & $\begin{array}{c}\text { SOCIALLY } \\
\text { ACCEPTED } \\
\text { SIGNIFICANCE }\end{array}$ & $\begin{array}{l}\text { MORPHOLOGICAL } \\
\text { ELEMENTS }\end{array}$ & $\begin{array}{c}\text { CHROMATIC } \\
\text { ELEMENTS }\end{array}$ \\
\hline 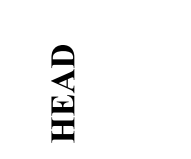 & Sunlight. & & $\sum$ \\
\hline $\begin{array}{l}\bar{z} \\
0 \\
\frac{z}{x}\end{array}$ & $\begin{array}{l}\text { The four most } \\
\text { important or } \\
\text { representative } \\
\text { festivals of the } \\
\text { indigenous world } \\
\text { - Inti Raymi } \\
\text { - Pawkar Raymi } \\
\text { - Coya Raymi } \\
\text { - Cápac Raymi }\end{array}$ & & \\
\hline
\end{tabular}




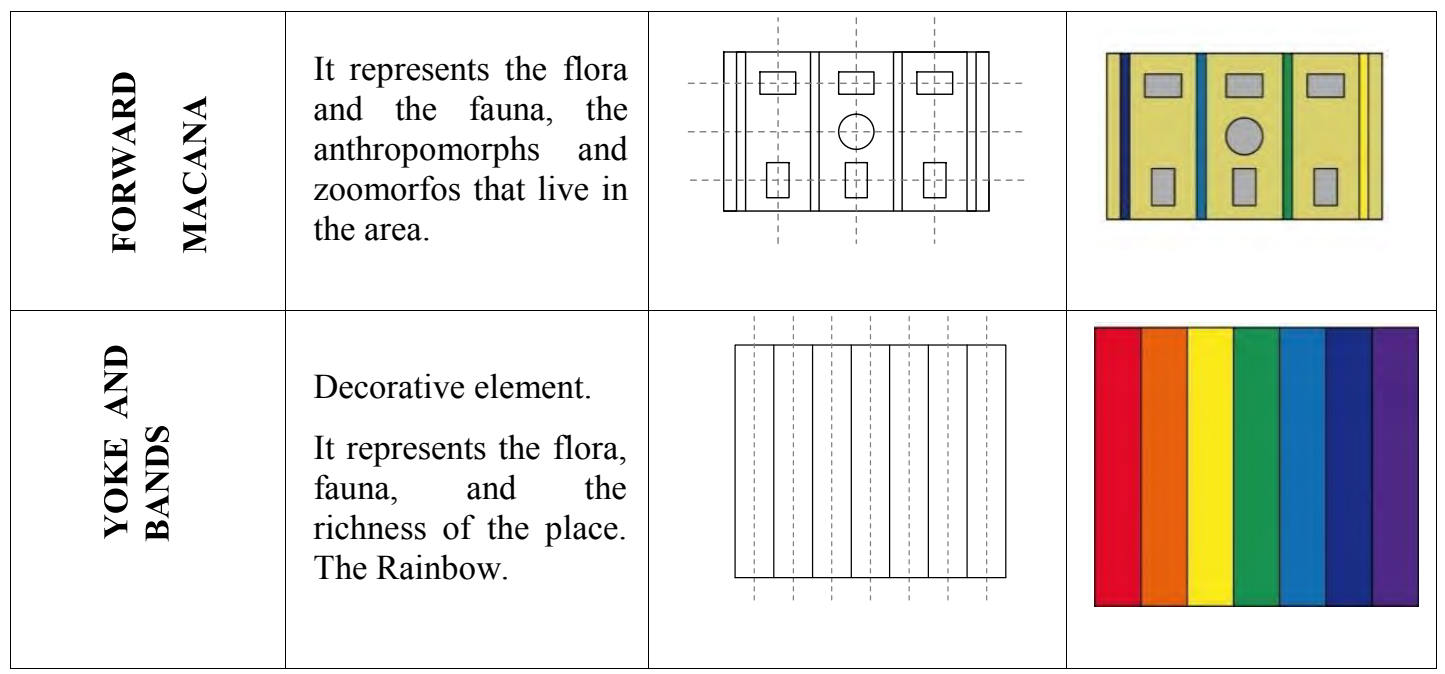

Based on this simplification, the design of the product is applied. The product is urban furniture (figures 2-6):

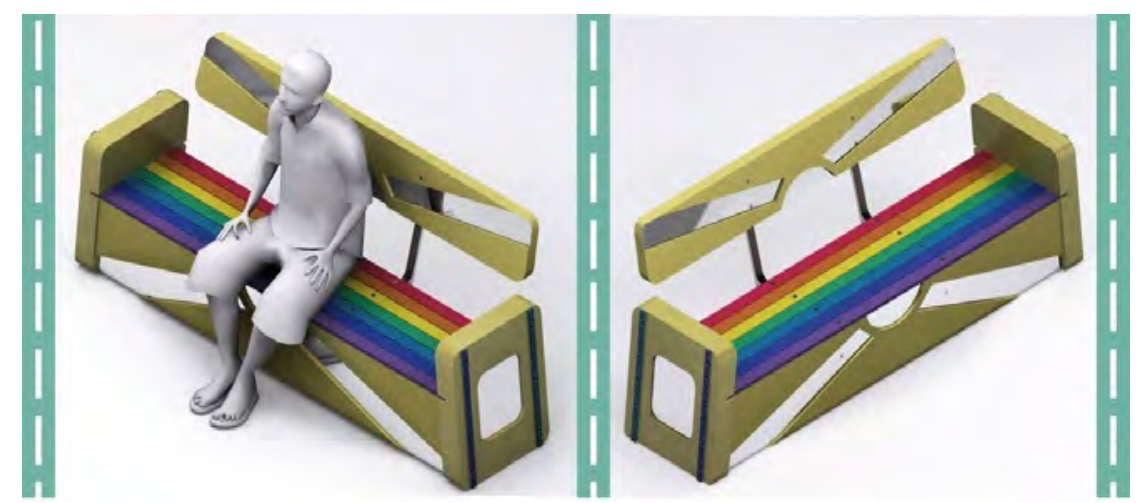

Figure 2. Bench

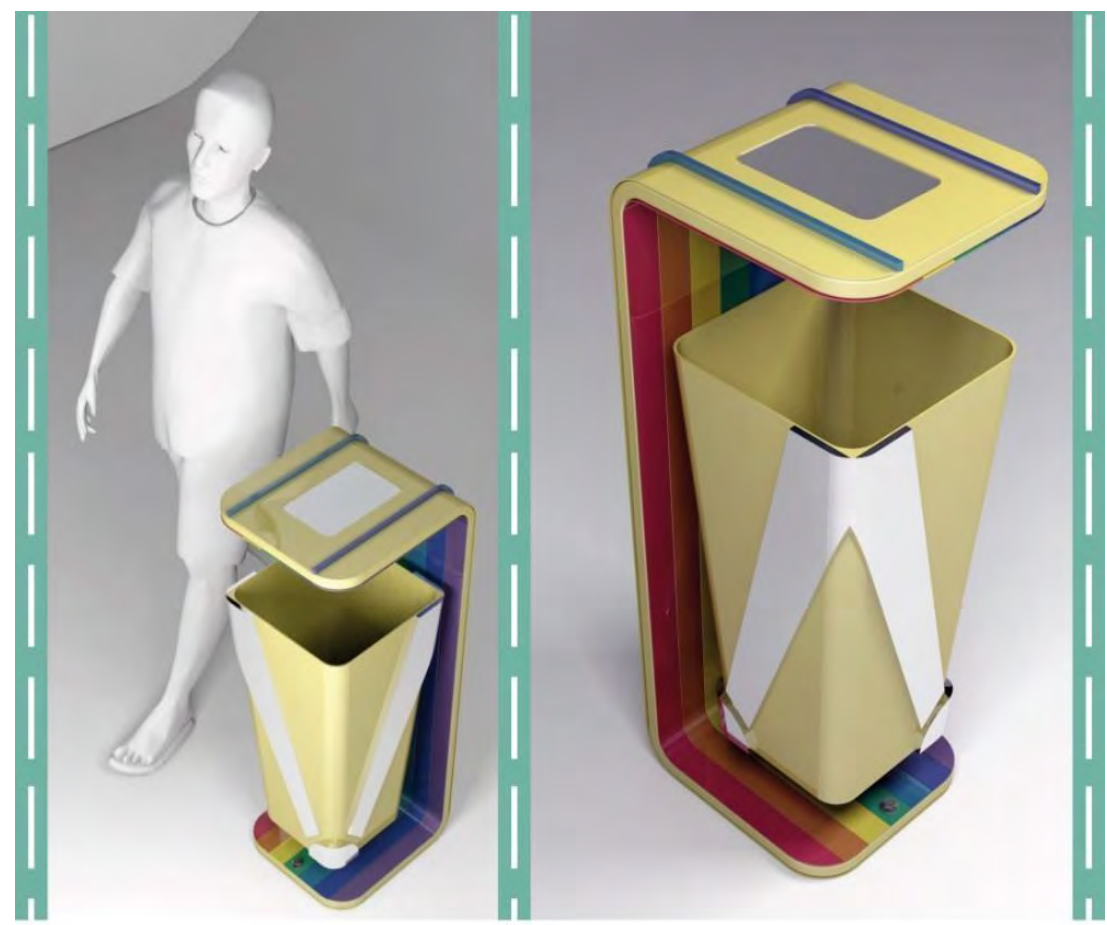

Figure 3. Garbage container 
Daniel Marcelo Acurio M. / The Academic Research Community Publication
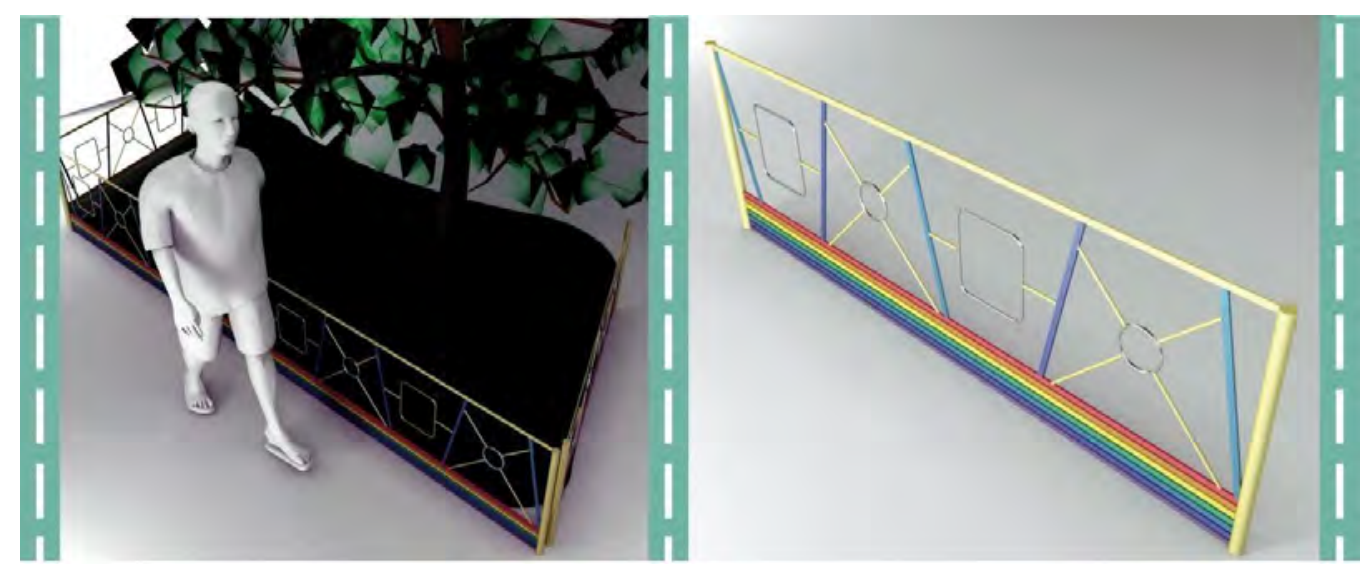

Figure 4. Fence

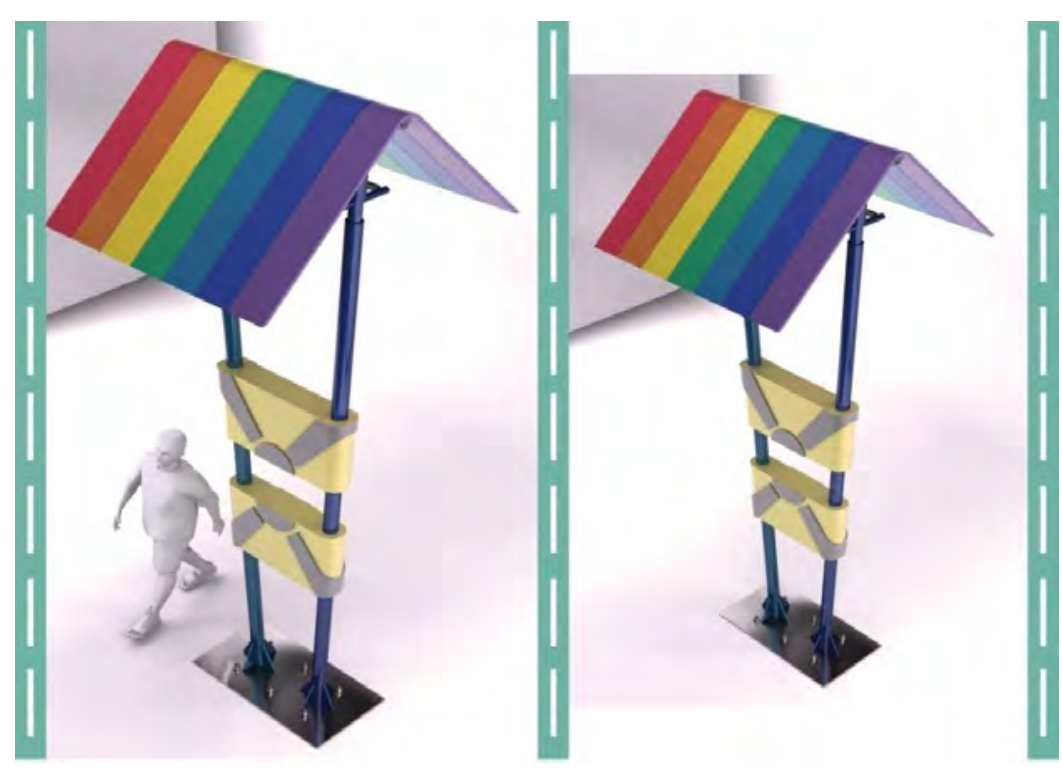

Figure 5. Lamp

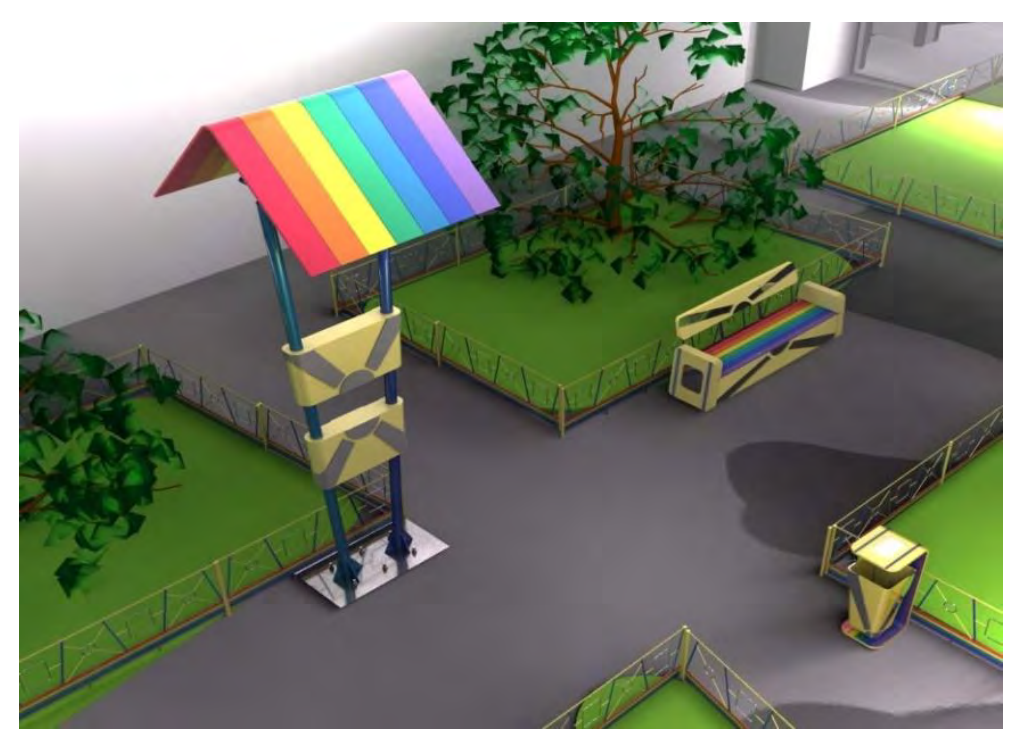

Figure 6. Bench, garbage container, fence and lamp 


\section{Conclusion}

Cultural manifestations are perceptible elements of a wide spectrum of a social, religious, intellectual, and effective group. They are expressed through their music, dance and other elements that are feasible to collect in order to decorate the design of environments, clothing and other products.

The method of iconographic description, applied as a description of visual components of a cultural manifestation, allows the extraction of representative elements that can be reinterpreted for application in the setting of parks.

The chromatic and morphological application in the design of products cannot fully absorb the richness of the cultural manifestations nor, in the aesthetic aspect, the depth of its meaning. Therefore, the simplification proposed to the iconographic - iconological method of Panofsky is suitable to extract a basic meaning that endows the product with identity and revalues the under study cultural manifestation.

The aesthetic contribution of the park makes it possible to boost tourism in the sector, thus allowing a cultural and innovative contribution to local production that translates into economic benefits due to being a place of interest in the locality.

Finally, this methodological proposal is an academic contribution that allows the designer to take advantage of the variety of cultural manifestations of Ecuador and Latin America as a source of aesthetic construction.

\section{References}

1. Bialostocki, J. (1973). Estilo e iconografía: contribución a una ciencia de las artes. Barral.

2. Colle, R. (1999). El contenido de los mensajes icónicos. Revista Latina de Comunicación Social, 2-72.

3. Herrera, S. \&. (2011). Corpus Christi, Intangible Heritage of Ecuador. Ab Initio N. 3, 45-57.

4. Herrera, S. \&. (2012). Corpus Christi, patrimonio intangible del Ecuador. RICIT N. 4, 71-86.

5. Johnston, A. (2013). Is the Sacred for Sale?: Tourism and Indigenous Peoples. London: Earthscan.

6. Kent, R. (2016). Latin America, Second Edition: Regions and People. New York: Guilford Publications.

7. Larraín, J. (1994). La identidad Latinoamericana Teoría e Historia. Estudios Públicos, 31-64.

8. Leon, E. (2014). Andes: Prehistoric Art. In Encyclopedia of Global Archaeology (pp. 234-238). New York, NY: Springer New York.

9. Mitchell, W. (2015). Image Science: Iconology, Visual Culture, and Media Aesthetics. Chicago: University of Chicago Press.

10. Montenegro, P. (2014). Equipamiento de Parques y Jardines para la Revalorización de Identidad Icónica del Corus Cristi. Ambato: PUCESA.

11. Newman, R. (2015). Primitivism and Identity in Latin America: The Appropriation of Indigenous Cultures in 20th-Century Latin $\begin{array}{llllll}\text { American Art. Ho Honors } & \text { Paper, } & \text { 1-103. Hetrieved }\end{array}$ http://digitalcommons.conncoll.edu/cgi/viewcontent.cgi?article=1002\&context=arthisthp

12. Olson, D., \& Bialystok, E. (2014). Spatial Cognition: The Structure and Development of Mental Representations of Spatial Relations. New York: Psychology Press.

13. Panofsky, E. (1987). Meaning in the Visual Arts. New York: Doubleday Anchor Books.

14. Panofsky, E. (1998). Estudios sobre iconología. Madrid: Alianza Editorial.

15. Porebski, M. (1969). About Iconographic Problems of Cubism. The Contens of a Work Art, 289.

16. Restrepo, L. (2013). Intermix: Traditional Pre-Columbian Art Meets Contemporary Design. Louisiana: Graduate Faculty of Louisiana State University and Agricultural and Mechanical College. Retrieved from http://etd.lsu.edu/docs/available/etd-11182013-154902/

17. Tartás, C., \& Guridi, R. (2013). Cartografías de la memoria. Aby Warburg y el Altas Mnemosyne. EGA: revista de expresión gráfica arquitectónica, 226-235.

18. Valiente, S. (2011). The Feast of Corpus Crhisti in the Kingdom of Castille during de Modern Age. RICIT N. 4, 71-86.

19. Villafañe, J. (1985). Introducción a la teoría de la imagen. Madrid: Ediciones Pirámide.

20. Zhang, X., \& Sheng, J. (2017). A Peircean semiotic interpretation of a social sign. Annals of Tourism Research, 163-173. 